\title{
PRODUCTIVITY ASSESSMENT \\ OF ALTERNATIVE TIMBER DEBARKING METHODS
}

\section{PROCJENA PRODUKTIVNOSTI ALTERNATIVNIH METODA KORANJA DRVNOG SORTIMENTA}

\author{
Neşe GÜLCl ${ }^{*}$, Abdullah E. AKAY², Orhan ERDAŞ ${ }^{1}$
}

\begin{abstract}
Summary
In Turkey, timber debarking stages are generally carried out by using axes. However, this method takes a lot of time and requires more work forces. In addition, since leaving residual trees with bark in stands increases the risk of insect damages, residual trees require quick barking process. In recent years, chainsaw mounted debarking tools have been widely used in debarking stages due to performing jobs quicker with less labor force. In this study, two different debarking methods including using axes and debarking tool were analyzed by considering operation productivity. The field studies were conducted in Brutian Pine (Pinus brutia Ten.) stand located in Bahçe Forest Enterprise Chief of Osmaniye Forest Enterprise Directorate in Adana Regional Forestry Directorate. As a result of study, the productivity of chainsaw mounted debarking tool was found to be five times higher than that of using axes for debarking. Thus, use of chainsaw mounted debarking tool is better alternative than use of axe in debarking activities, as it takes less time and minimize physical work load of the loggers.
\end{abstract}

KEY WORDS: Forest operations, debarking activity, chainsaw mounted debarking tool, debarking productivity

\section{INTRODUCTION}

\section{UVOD}

In Turkey, timber harvesting operation is consisted of series of successive activities including felling, bucking, debarking, wood extraction, loading, transportation, unloading, and timber stacking (Eker and Acar, 2006; Erdaş et al., 2014; Gülci, 2014). According to legal regulations, especially coniferous trees must be debarked just after felling stage (OGM, 1996). Thereby, organic material is to be kept inside the forest, and the amount of transported load is reduced by approximately $30 \%$ (Eker et al., 2011). Especially, barks are preferably left in the stand due to limited usage oppor- tunities of the barks in forest industry in Turkey (Acar et al., 2015). For this reason, in timber extraction with a consumer-wise sale idea, producer carry out stump-site debarking process without encountering any problems during furniture production and any financial loss in forestry industry (Marshall et al. 2006).

Although debarking studies do not appear as of the primary stages in timber extraction operations, it received great importance by means of research and evaluation in ecological and economic dimension (Magaggnotti et al. 2011; Gavrilov et al. 2016). Debarking is described as using various methods to remove tree barks from the trunk (Gürtan,

\footnotetext{
${ }^{1}$ Assit. Prof. Dr. Neşe Gülci, Prof. Dr. Abdullah E. Akay, Kahramanmaras Sutcu Imam University, Faculty of Forestry, 46100 Kahramanmaras, Turkey

2 Prof. Dr. Orhan Erdaş, Bursa Technical University, Faculty of Forestry, 16330 Bursa, Turkey

${ }^{*}$ Corresponding author e-mail: nesegulci@gmail.com
} 
1969). Debarking activities should be carried out in advance because hard objects like stone and sand that are stuck in barks can damage the saw tooth and decrease productivity during the timber process in sawmills. Also, blunts occurred on the debarking machine knives damage the heartwood, which reduces their quality (Watson et al. 1993).

In harvesting activities, which are usually performed in spring and summer months, unbarked products that are left in forests are confronted with the risk of bark beetles. Thus, one of the most important reasons of debarking is to prevent damages of bark beetles between the bark and the wood of harvested trees (FAO, 2011). Besides, debarking activities should be completed until the end of April at last, otherwise not only harvested trees but also the residual standing trees can be also damaged by these beetles (Gürtan, 1969).

The efficiency and productivity of debarking activity is affected by many factors such as the types of the equipment, physical structure of the workers, tree species and diameter, bark thickness, harvesting period, the time between felling and debarking, ground slope, and weather condition (Gürtan, 1969; Çoban, 1975). Debarking activities of coniferous trees in Turkey are performed by using axe or chainsaw mounted debarking tool.

Debarking with axe is performed by starting from the thicker part of the trunk to its thinner part (Ylldırım, 1989). Debarking of trees with thick barks is performed by removing barks as long strips. For debarking trees with relatively thinner barks, chainsaw mounted debarking tools are often preferred. These tools are located on the metal plates of the chainsaw and receive the power from the chainsaw engine (Eker and Acar, 2004; Gülci, 2014). During debarking with axe, workers mostly work by bending down, so in this case muscle power is heavily used. During debarking with a cha- insaw mounted debarking tool, however, workers also work by bending down, but in this case they use engine power, and they complete the work by moving only back and forth (Eker et al., 2011).

Debarking tools used in debarking studies that are carried out with traditional and developed methods differ according to the tree species, location and economy. Nowadays, while countries with lack of mechanization in forestry use manual devices (like attachable apparatus for axe and chainsaw) for debarking, countries with various forestry mechanization options prefer different mechanical debarking tools (chain flail debarker, harvester head for debarking and etc.) (Watson et al., 1993; Eker et al., 2011; Murphy and Acuna, 2016).

There are various factors for choosing debarking method in forest harvesting, for certain. It is an important decision whether to remove the barks at the stump-site, or debark them in wood processing mills. Logging residuals (bark, leave, branch, etc) of economically valuable trees are evaluated as fuel in generating bio-energy, or thanks to their chemical content, bio-products are obtained from logging residuals to gain economic value (Magaggnotti et al. 2011).

The productivity of the equipment and techniques used during debarking activity are generally determined based on operation time. The most commonly used method for measuring the operation time is time study method (Ylldırım, 1987). Main material and tools used in time studies are timers (i.e. chronometer, palmtop, data loggers) and time study forms. In addition, devices for measuring distance and operation speed, camera, clinometer, steel tape, caliper are used in time study work in the field (Yıldırım, 1987; Gülci, 2014; Manavakun, 2014).

In this study, it was aimed to evaluate two common debarking methods using axe and chainsaw mounted debarking

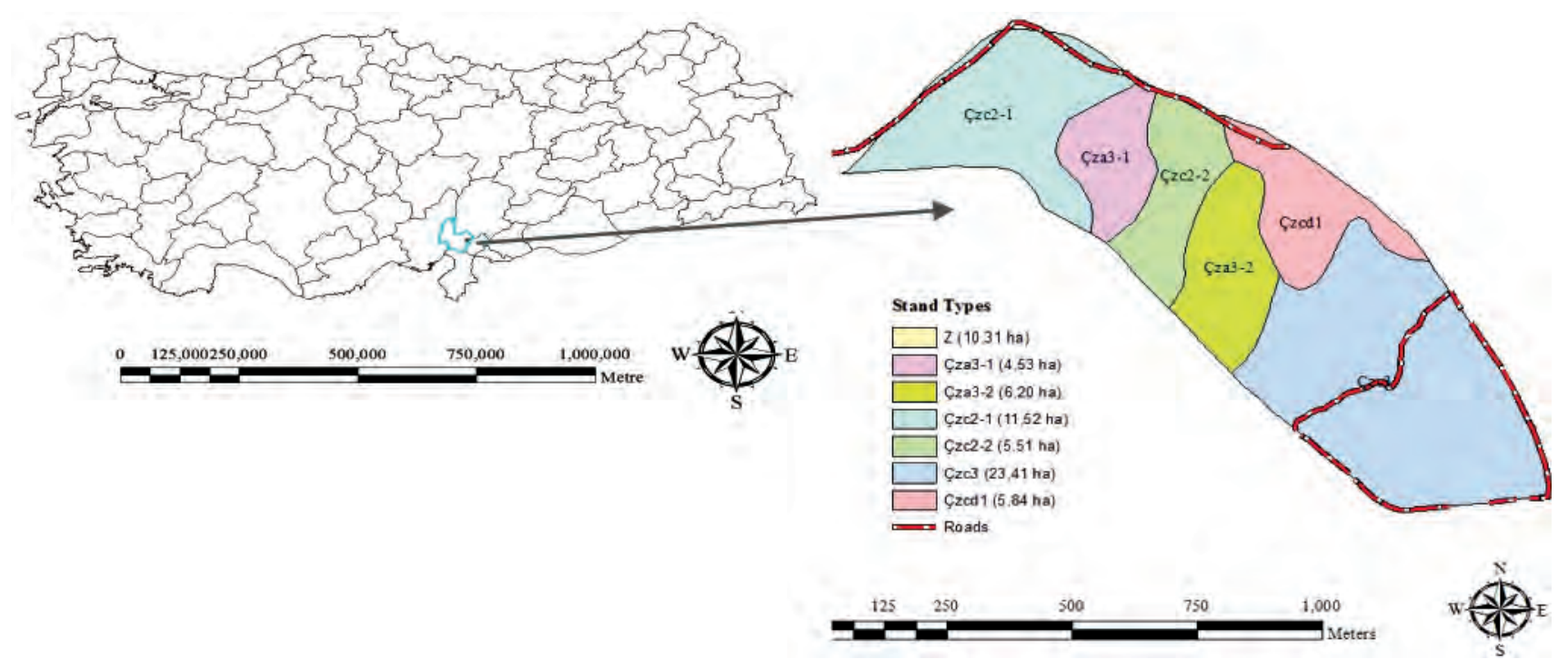

Figure 1. Study area

Slika 1. Područje istraživanja 


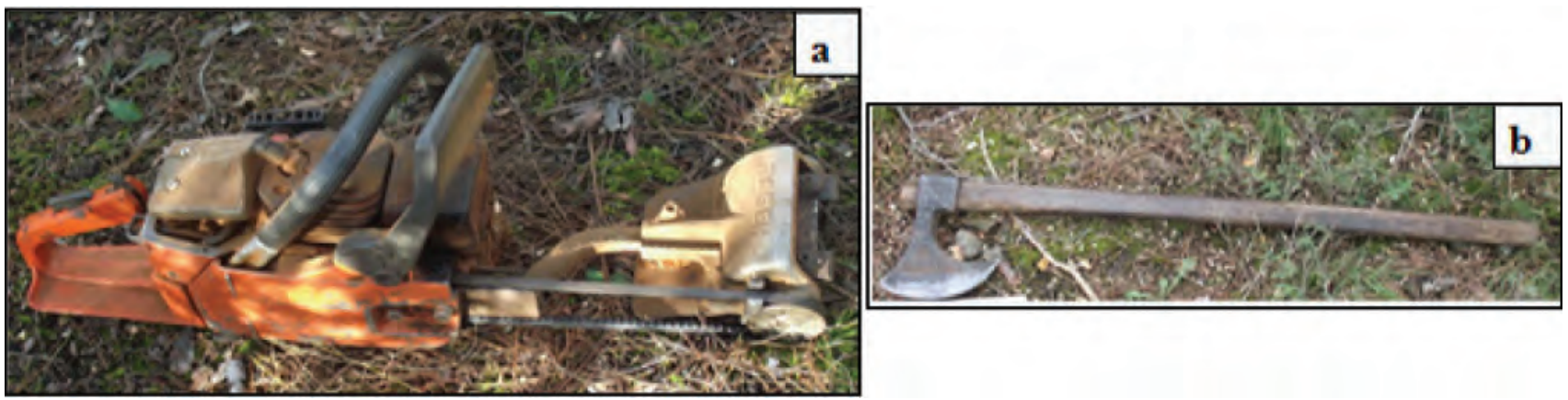

Figure 2. Chainsaw mounted debarking tool (a), and axe (b)

Slika 2. Guljač kore montiran na motornu pilu (a) i sjekira (b)

tool. The study application was conducted in stand of Turkish red pine (Pinus brutia Ten.) within the borders of Bahçe Forest Enterprise Chief, in Osmaniye, Turkey. The productivity of two methods was investigated based on time study approach.

\section{MATERIAL AND METHOD MATERIJAL I METODA}

\section{Material}

The study was conducted during a thinning operation taken place in Stand Compartment 127 within the borders of Bahçe Forest Enterprise Chief located in Osmaniye Enterprise Directorate of Adana Regional Forest Directorate. Dominant tree species in the study area was mainly Turkish red pine (Pinus brutia Ten.) (Figure 1). The study field is located between $37^{\circ} 11^{\prime} 18^{\prime \prime}-37^{\circ} 10^{\prime} 41^{\prime \prime}$ North latitude and $33^{\prime} 44^{\prime \prime}-36^{\circ} 34^{\prime} 46^{\prime \prime}$ East longitude. Average ground slope and elevation were $32.73 \%$ and $683 \mathrm{~m}$, respectively.

In the study area, small-diameter timbers and medium-diameter timbers in short length class, mine poles, and industrial wood were produced. A „Husqvarna 61” brand cha-

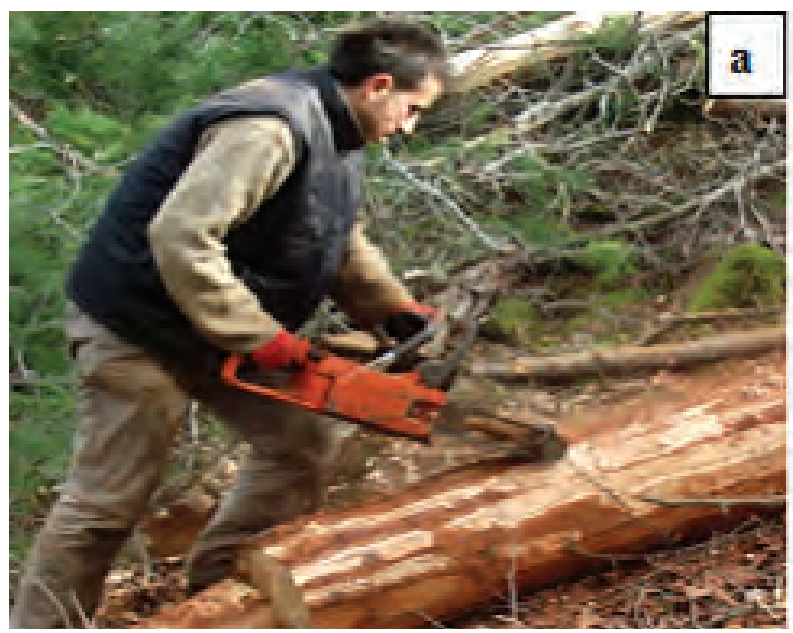

insaw, a chainsaw mounted debarking tool and an axe were used in debarking activity (Figure 2). During measurement of the medium-diameters and length of the timber, „MANTAX Precision" brand calipers and „Weiss" brand 50 meters steel tape were used, respectively. At the same time, bark thickness was determined by a bark gauge by measuring from both ends of the timber. Operation time during debarking was measured by two chronometers (Selex 7064).

This study was conducted by two workers, one work with a chainsaw mounted debarking tool and one with an axe (Figure 3). SPSS software package was used for statistical analyses. At the beginning of the field studies, after observing the debarking activities, a time study form was developed for recording the time measurements of each work stage of the operation.

\section{Time Study - Mjerenje rada}

Work stages investigated during debarking are debarking and turning the timber (primary activity), preparation (secondary activity) and small repairs and maintenance (additional activity). In order to prevent any operational bias during work stage, data was collected during debarking ac-

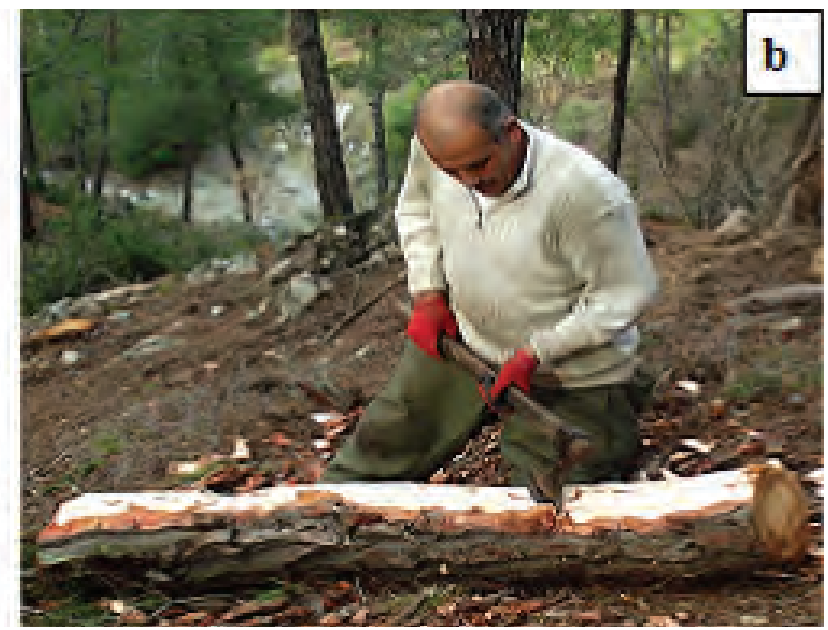

Figure 3. Debarking with debarking tool (a) and axe (b)

Slika 3. Koranje guljačem kore (a) i sjekirom (b) 
tivity done by the same worker. The walking time stage was ignored since the timber to be debarked were located within very close distance to each other in the study area. Work stages like cleaning the surrounding area of the timber, starting the chainsaw or holding the axe were considered as preparation stage.

The duration of time between the starting and ending of the debarking was considered as debarking time. During debarking, the workers turn the timber with their foot for enabling the side and back parts to be debarked. At this stage, the duration of time was considered as the timber turning time. For statistical analysis of the debarking activity, total of 120 measurements at the field were recorded; 60 of them were debarked by an axe, while other 60 were done by the debarking tool.

\section{Productivity Analysis - Analiza produktivnosti}

The effects of the timber volume on productivity of debarking were investigated. For this purpose, timber volumes were grouped under three classes (low: $<0.08 \mathrm{~m}^{3}$, medium: $0.08 \mathrm{~m}^{3}-0.12 \mathrm{~m}^{3}$, high: $>0.12 \mathrm{~m}^{3}$ ) in order to investigate different volume classes within the debarking studies with axe and chainsaw mounted debarking tool. Total cycle time was determined as a dependent variable (y), while independent variables were determined as; timber diameter $\left(\mathrm{x}_{1}\right)$, bark thickness $\left(\mathrm{x}_{2}\right)$ and its volume $\left(\mathrm{x}_{3}\right)$.

„Huber's Formula”, one of the most commonly preferred formula in technical forestry application, was used for calculating the volumes of the timber (Carus, 2002). It was calculated with the product volume $\left(V_{i}\right)$, medium diameter and length as given below in Formula 1:

$$
V_{i}=\frac{\pi}{40000} d_{i}^{2} L_{i}
$$

$\mathrm{d}_{\mathrm{i}}=\mathrm{i}$ medium diameter of the timber $(\mathrm{cm})$

$\mathrm{L}_{\mathrm{i}}=\mathrm{i}$ length of the timber $(\mathrm{m})$

Then, using the data that were obtained with time measurement, hourly productivity ( $\mathrm{P}$ in $\mathrm{m}^{3}$ /hour) was investigated. „Formula 2" was used for productivity calculation as follows:

$$
\mathrm{P}=(\mathrm{V} / \mathrm{T})^{\star} 60
$$

$\mathrm{P}=$ Productivity $\left(\mathrm{m}^{3} /\right.$ hour $)$

$\mathrm{V}=$ Timber volume in a cycle $\left(\mathrm{m}^{3}\right)$

$\mathrm{T}=$ Total time in a cycle (hour)

$60=$ Coefficient used for converting minute to hour

The effect of different volume classes (low, medium, high) on productivity of debarking was investigated with OneWay Anova analysis (Akay et al., 2010). As the differences between the averages and number of samples were equal, Tukey multiple comparison test was used (Kayri, 2009). „Pearson Correlation” was applied to find out the relation of the variables that effects the time values of the debarking studies with the timber diameter, bark thickness, volume (independent variable) and total cycle time (dependent variable). „Linear Regression Analysis” was carried out to determine the mathematical models of the independent variables (diameter, bark thickness). When the volume variable was included to the regression analysis, the model did not give a confidence level of $95 \%$ sensible result ( $p>0,05)$; therefore, volume was not included in regression analysis of both methods.

\section{RESULTS AND DISCUSSION} REZULTATI I RASPRAVA

In debarking application, using a chainsaw mounted debarking tool, minimum and maximum timber diameter was determined as $13 \mathrm{~cm}$ and $30 \mathrm{~cm}$ (Table 1). Total average debarking cycle time was determined as $1.30 \mathrm{~min} /$ timber, with the average bark thickness of $1.40 \mathrm{~cm}$. There were only two groups of timber lengths including $1.4 \mathrm{~m}$ and $2.0 \mathrm{~m}$ long timbers, therefore, timber length was excluded from statistical analysis to prevent contradictory interpretation.

In debarking activity using an axe, minimum and maximum timber diameter was determined as $13 \mathrm{~cm}$ and $35 \mathrm{~cm}$

Table 1. Statistical results of productivity variables for debarking with chainsaw mounted debarking tool

Tablica 1. Statistički rezultati varijabli produktivnosti za koranje guljačem kore montiranim na motornu pilu

$\begin{array}{lcccc}\text { Variables / Varijable } & \text { Min. } & \text { Max. } & \begin{array}{c}\text { Mean/ } \\ \text { Srednja } \\ \text { vrijednost }\end{array} & \begin{array}{c}\text { Std. Deviation / } \\ \text { Standardna } \\ \text { devijacija }\end{array} \\ \begin{array}{l}\text { Timber diameter / } \\ \text { Promjer drvnog } \\ \text { sortimenta (cm) }\end{array} & 13,00 & 30,00 & 20,28 & 3,96 \\ \begin{array}{l}\text { Timber volume / } \\ \text { Obujam drvnog } \\ \left.\text { sortimenta (m }{ }^{3}\right)\end{array} & 0,03 & 0,14 & 0,07 & 0,03 \\ \begin{array}{l}\text { Timber bark thickness / } \\ \text { Debljina kore drvnog } \\ \text { sortimenta }(\mathrm{cm})\end{array} & 0,50 & 2,50 & 1,40 & 0,63\end{array}$

Table 2. Statistical results of productivity variables for debarking with axe

Tablica 2. Statistički rezultati varijabli produktivnosti za koranje sjekirom

$\begin{array}{lcccc}\text { Variables / Varijable } & \text { Min. } & \text { Max. } & \begin{array}{c}\text { Mean / } \\ \text { Srednja } \\ \text { vrijednost }\end{array} & \begin{array}{c}\text { Std. Deviation / } \\ \text { Standardna } \\ \text { devijacija }\end{array} \\ \begin{array}{l}\text { Timber diameter / } \\ \text { Promjer drvnog } \\ \text { sortimenta }(\mathrm{cm})\end{array} & 13,00 & 35,00 & 22,22 & 6,38 \\ \begin{array}{l}\text { Timber volume / } \\ \text { Obujam drvnog } \\ \text { sortimenta }\left(\mathrm{m}^{3}\right)\end{array} & 0,03 & 0,19 & 0,08 & 0,05 \\ \begin{array}{l}\text { Timber bark thickness / } \\ \text { Debljina kore drvnog } \\ \text { sortimenta }(\mathrm{cm})\end{array} & 1,00 & 4,00 & 3,05 & 0,96\end{array}$


Table 3. One-Way ANOVA analysis results for debarking with chainsaw mounted debarking tool Tablica 3. Rezultati analize jednosmjerne ANOVE za koranje uz pomoć guljača montiranog na motornu pilu

$\begin{array}{lcccccccc}\text { Volume Classes / } & \begin{array}{c}\text { Number } \\ \text { of Sample / } \\ \text { Klase obujma }\end{array} & \begin{array}{c}\text { Average } \\ \text { Productivity / } \\ \text { uzoraka }\end{array} & \begin{array}{c}\text { Std. } \\ \text { Prosječna } \\ \text { produktivnost }\end{array} & \begin{array}{c}\text { Std. } \\ \text { Standardna } \\ \text { devijacija }\end{array} & \begin{array}{c}\text { 95\% C.I. For Mean / } \\ \text { Error/ } \\ \text { Standardna } \\ \text { pogreška }\end{array} & \begin{array}{c}\text { 95\% C.I. za srednju vrijednost } \\ \text { Lower Bound / Upper Bound/ } \\ \text { Donja granica }\end{array} \text { Gornja granica } & \text { Min. } & \text { Max. } \\ \text { Low / Niska } & 44 & 3,54 & 0,62 & 0,09 & 3,35 & 3,73 & 2,43 & 4,33 \\ \text { Medium / Srednja } & 14 & 2,90 & 0,55 & 0,14 & 2,58 & 3,22 & 2,36 & 4,16 \\ \text { High / Visoka } & 2 & 2,39 & 0,02 & 0,02 & 2,13 & 2,64 & 2,37 & 2,41 \\ \text { Total / Ukupno } & 60 & 3,35 & 0,67 & 0,08 & 3,18 & 3,53 & 2,36 & 4,33\end{array}$

Table 4. One-Way ANOVA analysis results for debarking with axe Tablica 4. Rezultati analize jednosmjerne ANOVE za koranje uz pomoć sjekire

$\begin{array}{lcccccccc}\text { Volume Classes / } & \begin{array}{c}\text { Number } \\ \text { of Sample / } \\ \text { Klase obujma }\end{array} & \begin{array}{c}\text { Average } \\ \text { Productivity / } \\ \text { Prosječna } \\ \text { uzoraka }\end{array} & \begin{array}{c}\text { Std. } \\ \text { Deviation / } \\ \text { Standardna } \\ \text { pevijacija }\end{array} & \begin{array}{c}\text { Std. } \\ \text { Error/ } \\ \text { Standardna } \\ \text { pogreška }\end{array} & \begin{array}{c}\text { 95\% C.I. For Mean / } \\ \text { 95\% C.I. za srednju vrijednost } \\ \text { Lower Bound / } \\ \text { Donja granica }\end{array} & \begin{array}{c}\text { Upper Bound / } \\ \text { Gornja granica }\end{array} & \text { Min. } & \text { Max. } \\ \text { Low / Niska } & 34 & 0,54 & 0,06 & 0,01 & 0,52 & 0,56 & 0,44 & 0,72 \\ \text { Medium / Srednja } & 17 & 0,68 & 0,06 & 0,01 & 0,65 & 0,71 & 0,52 & 0,78 \\ \text { High / Visoka } & 9 & 0,89 & 0,09 & 0,03 & 0,82 & 0,97 & 0,78 & 1,04 \\ \text { Total / Ukupno } & 60 & 0,63 & 0,14 & 0,01 & 0,60 & 0,67 & 0,44 & 1,04\end{array}$

Table 5. Results of correlation tests for debarking

Tablica 5. Rezultati korelacijskih testova za koranje

\begin{tabular}{|c|c|c|c|}
\hline \multirow[b]{2}{*}{$\begin{array}{l}\text { Variables / } \\
\text { Varijable }\end{array}$} & & Tool / Alat & Axe / Sjekira \\
\hline & & $\begin{array}{c}\text { Total time / } \\
\text { Ukupno } \\
\text { vrijeme (y) }\end{array}$ & $\begin{array}{c}\text { Total time / } \\
\text { Ukupno } \\
\text { vrijeme (y) }\end{array}$ \\
\hline \multirow{3}{*}{$\begin{array}{l}\text { Diameter / } \\
\text { Promjer }\left(\mathrm{x}_{1}\right)\end{array}$} & $\begin{array}{c}\text { Correlation coefficient / } \\
\text { Koeficijent korelacije }\end{array}$ & $0,95^{* *}$ & $0,94^{* *}$ \\
\hline & $P$ & 0,00 & 0,00 \\
\hline & $\mathrm{N}$ & 60 & 60 \\
\hline \multirow{3}{*}{$\begin{array}{l}\text { Bark Thickness / } \\
\text { Debljina kore }\left(x_{2}\right)\end{array}$} & $\begin{array}{c}\text { Correlation coefficient / } \\
\text { Koeficijent korelacije }\end{array}$ & $0,95^{* *}$ & $0,82^{* *}$ \\
\hline & $P$ & 0,00 & 0,00 \\
\hline & $\mathrm{N}$ & 60 & 60 \\
\hline \multirow{3}{*}{$\begin{array}{l}\text { Volume / } \\
\text { Obujam }\left(x_{3}\right)\end{array}$} & $\begin{array}{c}\text { Correlation coefficient / } \\
\text { Koeficijent korelacije }\end{array}$ & $0,98 * *$ & $0,94^{* *}$ \\
\hline & $P$ & 0,00 & 0,00 \\
\hline & $\mathrm{N}$ & 60 & 60 \\
\hline
\end{tabular}

(Table 2). With the average bark thickness of $3.05 \mathrm{~cm}$, total average debarking cycle time was determined as $6.91 \mathrm{~min} /$ timber.

One-Way Anova analysis results for debarking studies using a chainsaw mounted debarking tool are given in Table 3. The results showed that different volume classes have a significant statistical effect $(\mathrm{p}<0.01)$ on the productivity. The average productivity $\left(3.54 \mathrm{~m}^{3} /\right.$ hour $)$ of low volume timbers was found to be higher than the medium $\left(2.90 \mathrm{~m}^{3} /\right.$ hour $)$ and high $\left(2.39 \mathrm{~m}^{3} /\right.$ hour$)$ volume classes.

The results of debarking activity using an axe showed that different volume classes have also a significant statistical ef- fect $(\mathrm{p}<0.01)$ on the productivity. According to One-Way Anova analysis results, average productivity increased from low volume class $\left(0.54 \mathrm{~m}^{3} /\right.$ hour $)$, to medium $\left(0.68 \mathrm{~m}^{3} /\right.$ hour $)$ and high volume class $\left(0.89 \mathrm{~m}^{3} /\right.$ hour $)$ (Table 4$)$. In contrast to debarking using a chainsaw mounted debarking tool, debarking activity with an axe was determined to be more productive in high volume timbers.

The correlation test results of debarking activities were given in Table 5 . In both methods, it was determined that a significant relation $(\mathrm{p}=0.00, \mathrm{p}<0.01)$ was determined at a confidence level of $95 \%$ between all the other variables in both methods. Based on the operational experiences, loggers tent to use chainsaw mounted debarking tool for relatively thinner barks during forest operation in the field. Therefore, average bark thicknesses were lower comparing with debarking activity using an axe.

$\mathrm{R}^{2}$ values of the regression models by using a chainsaw mounted debarking tool and an axe were found as 0.97 and 0.94 , respectively. Also, the regression model gave a significant $(\mathrm{p}=0.00, \mathrm{p}<0.01)$ result in both of the methods at a confidence level of $99 \%$. Including the diameter $\left(\mathrm{x}_{1}\right)$, bark thickness $\left(\mathrm{x}_{2}\right)$ and volume $\left(\mathrm{x}_{3}\right)$ in solution process, with the dependent variable of the total time (y), regression model parameters for both methods were evaluated (Table 6).

According to the results, it was found that total time is directly proportional to diameter, bark thickness, and volume in both methods (Figure 4). Increase in timber sizes caused the workers to spend more time for debarking activity. Besides, timbers with thicker barks took more debarking cycle time. 
Table 6. Regression model parameters for debarking Tablica 6. Parametri regresijskog modela za koranje

$\begin{array}{lrc} & \text { Tool / Alat } & \text { Axe / Sjekira } \\ \text { Constant / Konstanta } & -0,94 & 0,152 \\ \mathrm{X}_{1} & 0,03 & 0,10 \\ \mathrm{X}_{2} & 0,23 & 0,65 \\ \mathrm{X}_{3} & 17,77 & 32,23 \\ \mathrm{R}^{2} & 0,97 & 0,94 \\ \text { Sig. } & 0,00 & 0,00\end{array}$
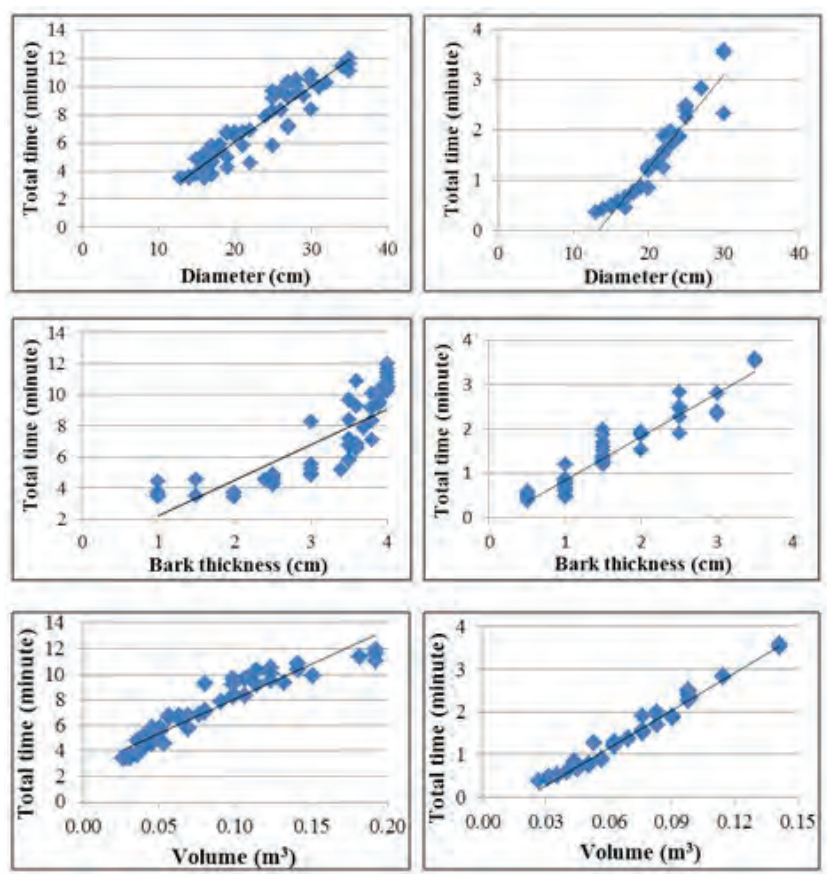

Figure 4. The relation between total time and diameter and bark thickness for debarking with axe (left) and chainsaw mounted debarking tool (right)

Slika 4. Odnos između vremena I promjera te debljine kore za koranje sjekirom (lijevo) te guljača montiranog na motornu pilu

Average percentage values according to total time of the debarking studies with chainsaw mounted debarking tool and axe working stages are seen in Table 7. When the working stages are compared to their percentages, while debarking stage took more time than the others, preparation stage took less time. The bark thickness, where the chainsaw mo-

Table 7. Statistical results of total time (\%) in work sections Tablica 7. Statistički rezultati ukupnog vremena (\%) u radnim sekcijama

\begin{tabular}{lcc} 
Working stages / Radne faze & \multicolumn{2}{c}{ Methods / Metode } \\
& Tool / Alat & Axe / Sjekira \\
Preparation / Priprema (\%) & 8,46 & 6,09 \\
Debarking / Koranje (\%) & 80,77 & 87,68 \\
Turning the timber / & 10,77 & 6,23 \\
Okretanje drva (\%) & 100,00 & 100,00 \\
Total / Ukupno (\%) &
\end{tabular}

unted debarking tool was used, was thinner compared to other diameters where axe was preferred. It was determined that turning the timber with debarking tool took much more time than with axe. The reason for this is that the worker's ability of movement is limited due to weight of the chainsaw. In a similar study by Eker et al. (2011), it was reported that debarking stage using chainsaw mounted debarking tool carried out in a Turkish red pine stand took a plenty of time (89.7\%), while preparation stage (3.7\%) took the least time.

According to obtained results, it was determined that hourly average productivity with a chainsaw mounted debarking tool and an axe was $3.36 \mathrm{~m}^{3} /$ hour and $0.64 \mathrm{~m}^{3} /$ hour, respectively. It was also found that while productivity of debarking with axe increases by volume classes, it was just the opposite in the case of using a chainsaw mounted debarking tool. This is because bark thickness increases relatively with the increase of volume.

It was determined that hourly productivity was five times higher when chainsaw mounted debarking tool was used, compared to axe. In a study conducted by Eker et al. (2011), it was also found that hourly productivity was about five times higher when compared to debarking with axe. In a similar study carried out by Eker and Acar (2004) in a Turkish red pine stand, it was determined that using a chainsaw mounted debarking tool was three times more productive than using an axe.

While productivity increases in studies where the chainsaw debarking tool is used and the bark thickness reaches up to $2.5 \mathrm{~cm}$, it remains constant where the bark thickness pass over $2.5 \mathrm{~cm}$. In case of studies where axe is used and the bark thickness reaches up to $2.5 \mathrm{~cm}$, productivity remains constant, but an increase was observed when the bark thickness passed over $2.5 \mathrm{~cm}$. (Figure 5). That is why maximum bark thickness was determined as $2.5 \mathrm{~cm}$ in order to use the chainsaw debarking tool efficiently. Also, when the bark thickness was over $2.5 \mathrm{~cm}$, axe was preferably used as a debarking alternative.

Even though debarking methods that are subject to this study are thought to be the optimum method for the current conditions in Turkey, using highly mechanized debarking techniques (chain flail debarker, harvester head for debarking and etc.) or using oriented processor (delimbre-debarker-chipper) at harvesting unit might be more productive. Economic value of the tree species can be considered as one of the most important factors in determination of optimum method (Spinelli et al. 2009; Magagnotti et al. 2011). However, debarking with chainsaw tools and axe are still more common in Turkey because logging residuals are not used as an economic product and usually left in the forests.

Even though debarking stage that is carried out inside the cutting area is not the primary stage of the logging opera- 

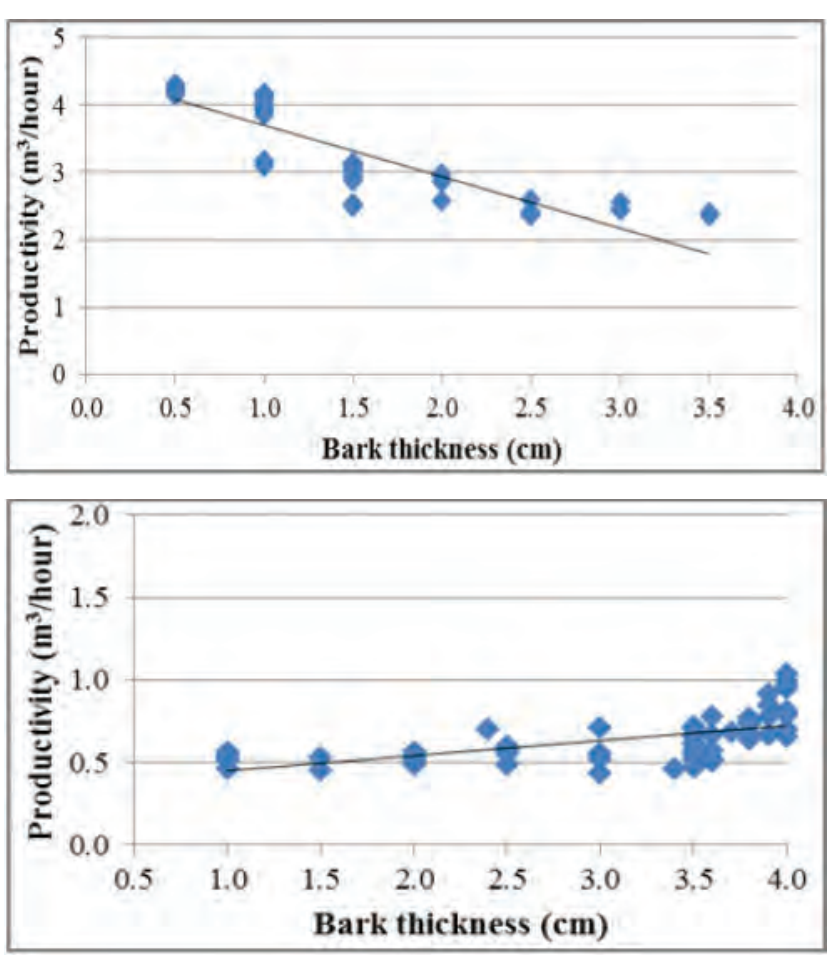

Figure 5. The relation between productivity and bark thickness for debarking with chainsaw mounted debarking tool (left) and axe (right)

Slika 5. Odnos između produktivnosti i debljine kore za koranje guljačem montiranog na motornu pilu (lijevo) i sjekirom (desno)

tion, it varies based on production time, production system and tools that are used (Murphy and Acuna 2016). The optimum method should be determined for cost optimization of debarking which is mostly preferred process in the extraction of coniferous species. Thereby, volume loss during debarking stages will be prevented and operational problems during log process will be eliminated.

\section{CONCLUSIONS AND SUGGESTIONS ZAKLJUČAK I PRIJEDLOZI}

In this study, debarking activities using a chainsaw mounted debarking tool and axe were investigated by means of productivity. In a stand where chainsaw mounted debarking tool was preferred for the debarking activity, it was found that average total debarking cycle time was $1.30 \mathrm{~min} / \mathrm{tim}$ ber while average bark thickness was $1.40 \mathrm{~cm}$. In other stand where an axe was used for the debarking studies, average total debarking cycle time was determined as $6.91 \mathrm{~min} / \mathrm{tim}$ ber while the average bark thickness was $3.05 \mathrm{~cm}$. According to the results, as the bark thickness increases, debarking time increases correspondingly.

The hourly average productivity of debarking using a chainsaw mounted debarking tool and an axe were $3.36 \mathrm{~m}^{3} /$ hour and $0.64 \mathrm{~m}^{3} /$ hour, respectively. As a result, hourly productivity was five times higher when using a chainsaw mounted debarking tool compared to axe.
It was determined that productivity was higher in low volume class, when the debarking activities were carried out by using chainsaw mounted debarking tool. On the other hand, the productivity was much higher in high volume class when the debarking was carried out by using an axe. Thus, in order to use the chainsaw mounted debarking tool efficiently, maximum bark thickness should not be exceeded (i.e. $2.5 \mathrm{~cm}$ ) and axe should be preferred otherwise.

The results showed that total time was directly proportional to diameter and bark thickness in both of the methods. Increase in timber and length caused the workers to spend more time in debarking activities. It was determined that in both methods, debarking took more time compared to other working stages.

Using a chainsaw mounted debarking tool in debarking activity can be considered as a good alternative when compared to an axe, as it takes less time and does not need much worker power. In fact, it would be inevitable to use chainsaw mounted debarking tool especially when the debarking activity of the timbers is considered to be completed in a short time due to the risk of the bark beetles.

\section{ACKNOWLEDGEMENTS ZAHVALA}

I would like to thank Dr. Sercan GÜLCİ and other reviewers for their pre-publication review and comments on this paper.

\section{REFERENCES LITERATURA}

- Acar, H.H., A.E. Akay, S. Gümüş, 2015: Mechanization in forestry, Karadeniz Technical University, Faculty of Forestry, Trabzon, 240 p.

- Akay, A.E., J. Sessions, H. Serin, M. Pak, N. Yenilmez, 2010: Applying optimum bucking method in producing Taurus Fir ( $A b$ ies cilicica) logs in Mediterranean Region of Turkey. Baltic Forestry 16(2):273-279.

- Carus, S., 2002: Comparison of some volume formulas regarding the stem, segments and fractions of the stem. Süleyman Demirel University Faculty of Forestry Journal (1):101-114.

- Çoban, C., 1975: An economic comparison of the new harvesting method on bark and unbarked long softwood logs with todays Turkish harvesting practice. Publications of the Turkish Forestry Research Institute, Technical Bulletin Serial 97 p.

- Eker, M.; H.H. Acar, 2004: A review on the log wizard using in terms of forest workmanship. X. Ergonomic Congress, 08-10 October 2004, Bursa.

- Eker, M., H.H. Acar, 2006: Operational planning method for timber harvesting. Süleyman Demirel University Faculty of Forestry Journal, 2:128-140.

- Eker, M.; H.H. Acar, H.O. Çoban, 2011: Time study and productivity analysis of chainsaw mounted log debarker in south- 
ern pine forests of Turkey. African Journal of Agricultural Research 6(10):2146-2156.

- Erdaş, O., H.H. Acar, M. Eker, 2014: Forest transportation technique. Karadeniz Technical University, Faculty of Forestry, Trabzon. 504 p.

- FAO, 2011: Guide to implementation of phytosanitary standards in forestry. FAO Forestry Paper 164. Food and Agricultural Organization (FAO). http://www.fao.org/docrep/013/i2080e/ i2080e.pdf.

- Gavrilov, T.A., T.B. Stankevich, O.A. Anpilogova, G.N. Kolesnikov, L.A. Chernyaev, 2016: Debarking waste processing: a systematic review. Resources and Technology 13(3):71-77. DOI: 10.15393/j2.art.2016.3521

- Gülci, N., 2014: Researches on precision forestry in forest planning. Phd thesis, Kahramanmaraş Sütçü İmam University, Faculty of Forestry, Kahramanmaraş, Turkey. 264 p.

- Gürtan, H., 1969: Die arbeitsleistungen verschiedener axte und schaleisen bei der entrindung. Forestry Research Institute in Ankara, Technical Bulletin, 38: 66.

- Kayri, M., 2009: The multiple comparison (post-hoc) techniques to determine the difference between groups in researches. Firat University Journal of Social Science 19(1):51-64.

- Magagnotti, N., C. Nati, L. Pari, R. Spinelli, R. Visser, 2011: Assessing the cost of stump-site debarking in eucalypt plantations. Biosys Eng. 110:443-449.
- Manavakun, N., 2014: Harvesting operations in eucalyptus plantations in Thailand. Dissertationes Forestales 177. Department of Forest Sciences, Faculty of Agriculture and Forestry, University of Helsinki. 111 p. doi: http://dx.doi.org/10.14214/df.177.

- Marshall, H.M., G.E. Murphy, B. Gartner, 2006: Effect of bark thickness estimates on optimal log merchandizing. For Prod J. 56:87-92.

- Murphy, G., M. Acuna, 2016: Effect of harvesting season, system and equipment on in-forest Pinus radiata bark removal in Australia and New Zealand. International Journal of Forest Engineering. http://dx.doi.org/10.1080/14942119.2016.1 253269.

- OGM, 1996: The notification of harvesting activities in woodbased forest products (Notification Number: 288), General Directorate of Forestry of Turkey, Ankara.

- Spinelli, R., S. Ward, P. Owende, 2009: A harvest and transport cost model for Eucalyptus spp. fast-growing short rotation plantations. Biomass and Bioenergy, 33:1265-1270.

- Ylldirım, M., 1987: Time study assessment in forest operations. Journal of the Faculty of Forestry Istanbul University 37(3):67-85.

- Yıldırım, M., 1989: Work science in forestry. İstanbul University Faculty of Forestry, İstanbul. 287 p.

- Watson, W.F., A.A. Twaddle, J.B. Hudson, 1993: Review of chain flail delimbing-debarking. Journal of Forest Engineering, $4(2): 37-52$.

\section{SAŽETAK}

U Turskoj se faze koranja drveta obično obavljaju uz pomoć sjekira. Međutim, ta metoda zahtijeva puno vremena i puno radne snage. Uz to, budući da ostavljanje drveta s korom u sastojinama povećava rizik od oštećenja insektima, zahtijeva hitan proces guljenja kore. Posljednjih godina puno se koriste guljači kore koji se montiraju na motornu pilu, budući da se posao obavlja brže s manjim brojem radne snage. U ovoj studiji, analizirane su dvije različite metode koranja u razmatranju produktivnosti rada koje uključuju uporabu sjekira i guljač kore koji se montira na motornu pilu. Terenske studije provedene su u sastojini brucijskog bora $(P i-$ nus brutia Ten.) koja se nalazi u Upravi šuma Bahçe u regionalnom šumskom gospodarstvu Adane. Rezultat studije bio je da je produktivnost pila za koranje bila pet puta veća od uporabe sjekira za koranje. Tako je guljač kore koji se montira na motornu pilu bolja alternativa od uporabe sjekire u guljenju kore, budući da je kod njega potrebno manje vremena te smanjuje fizički rad drvosječa.

KLJUČNE RIJEČI: Šumski radovi, koranje, guljač kore koji se montira na motornu pilu, produktivnost guljenja kore 